\title{
Characterization and Purification of Alkaline Proteases From Viscera of Silver Carp (Hypophthalmichthys molitrix) Fish
}

\section{*Atta, M.B. ${ }^{1}$; Shimaa El-Said Abd El-Hamed ${ }^{2}$ and Samia A. Keshk ${ }^{2}$}

${ }^{1}$ Food Science and Technology Department, Faculty of Agriculture, Tanta University ${ }^{2}$ Food Science and Technology Institute, Agriculture Research Center, Ministry of Agriculture

Received on: 20/11/2017

Accepted for publication on: 26/12/2017

\section{Abstract}

Proteases from viscera of Silver carp (Hypophthalmichthys molitrix) fish have been extracted and characterized. The alkaline proteases show optimum activity in $0.2 \mathrm{M}$ Tris- $\mathrm{HCl}$ buffer at $\mathrm{pH} 8.5$ and $45^{\circ} \mathrm{C}$ using soluble milk casein as substrate. The crude alkaline protease lost about $35 \%$ or $51 \%$ of its specific activity if it was heated at $50^{\circ} \mathrm{C}$ or kept at $\mathrm{pH} 9$ for 60 min., respectively. Purification of proteases purified by ammonium sulfate precipitation, gel-filtration using Sephadex G 50 column and ultrafiltration via polyamide membrane $(30 \mathrm{KDa})$ led to increase its specific activity up to 20, 24 and 99 fold, respectively.

Keywords: Silver carp, alkaline proteases, characterization, purification, specific activity

\section{Introduction:}

Protease enzymes (e.g. trypsin, chymotrypsin, chymosin or cathepsin-like) normally found in all living organisms. They are specific for breakdown the peptide linkages to create peptides and amino acids. There are four types of proteases according to their active site, namely serine (EC 3.4.21), cysteine (EC3.4.22) aspartic (EC 3.4.23) and metallo-proteases (EC 3.4.24) (John et al, 2003). Proteinases from animal, plant, and microbial sources have been used for enzymatic protein hydrolysis (Qian and Kim, 2007). These enzymes could be used as processing aid to transform foods into finished products. Where they are selective and specific for their substrates, which permits to produce food products free from contaminants and less toxicity (Lara-Márquez et al., 2011) or to generate bioactive peptides from proteins (Jiang et al., 2014). There- fore, a group of different types of enzyme may be used as a commercial enzyme in manufacture food product. Moreover, proteases are a powerful tool for modifying the properties of food proteins. They modify the functional properties such as emulsification, fat-binding, water-binding, foaming properties, gel strength, whipping properties (Sawant and Nagendran, 2014), as well as bioactive peptides synthesis (Zhong et al., 2011). Thus, proteases are using on a large scale in the food industry, where it is estimated to represent about $40-65 \%$ of the total commercial enzyme preparations in the global market (Zhang et al., 2009). In the industrial view, proteases can use as pharmaceutical agents (e.g. contactlens, enzyme cleaners, enzymatic deriders and reduce dental plaques) (Kumar and Suresh, 2016). Also, proteases find applications at various steps of leather processing such as 
de-haring (Dettmer et al., 2011), enzymatic soaking of salt-preserved buffalo hides (Deshpande et al, 2004) and for the recovery of silver from used X- ray film by decompose the gelatinous coating of X-ray films, from which silver is recovered (Gupta et al., 2002). Different alkaline proteases (alkaline proteases) produced by Bacillus $s p$ or extracted from industrial fish-waste may be used as effectively ingredient in detergent powder industry since 1963 . Nowadays, detergent enzymes account for $89 \%$ of the total proteases sales in the global market (Talita et al., 2009).

General, the amounts of fish processing waste is depending mainly on the type of final product, it could be accounted up to 80,66 and $27 \%$ from surimi, fillet as well as beheaded and gutted fish (Chandrasekaran, 2016).

The most common fish processing operation includes three steps: (a) beheaded and removing skin, (b) removing the tail and fins (c) eviscerated and boneless fish fillet. Fish waste is generated from the unwanted parts of the fish which can generally be divided into two types: (a) Solid waste including heads, tails, fins, frames, offal (guts, kidney and liver) and skin. (b) Liquid waste including waste water from cleaning the fish and equipment (IFC, 2011). About $70 \%$ of fish is processed and resulting in $20-80 \%$ of fish waste according to the level of processing and type of fish (Zhou et al., 2011). The presence of endogenous digestive enzymes in fish has been reported in numerous studies (Kishimura et al., 2008; Jellouli et al., 2009 and Xiong et al., 2011). The current global fisheries production of 93.4 million tons (81.5 million tons from marine waters and 11.9 million tons from inland waters), is rising as a result of increases in aquaculture production. Nowadays, the aquaculture provided only $39 \%$ for human fish consumption and wild-catch fish present $61 \%$ (FAO, 2016).

The total catches of fish in Egypt about 1.34 million tons per year (GAFRD, 2012) which will be expected to increase more than 1.5 million tons (FAO, 2010).

Fish products for human consumptions include fresh, frozen, whole, fillet and other innovative products (Vannuccini, 2004). Most discards composed of head, intestine, skin, bones and viscera reflects the amounts of fish processing waste (Khoddami et al., 2009). In fish, adaptive changes in the activity of proteolytic enzymes have been reported in relation to diet. Activity of internal enzymes is influenced by nutritional conditions of fish where they live and the circumstances which adapt those (German et al., 2010).

Tilapia fish is popular in Egypt, whether it is wild-capture or farmed followed by Mullet fish. Although the consumer acceptance of carp fish is low, it represents the third rank of farmed fish (Mohamed et al., 2012). Tilapia represents $78 \%$ of total production of aquaculture while the mullet and carp represent 12 and $10 \%$, respectively, (GAFRD, 2004).

Silver carp (Hypophthalmichthys molitrix) is a kind of fresh water aquaculture species. Huge amounts of silver carp by products (heads, skin, bone, scales and viscera) are produced during the fish processing. This 
became as resources of hazard environmental pollution resources wastes (Zhang et al., 2009). Viscera is one of the most important by products delivered digestive enzymes, especially proteases that have high activity over a wide range of $\mathrm{pH}$ and temperature conditions (Kumar et al., 2016). The environmental had effects condition and type of food in fish environment on the characteristics of the extracted enzyme especially the temperature and $\mathrm{pH}$ (Ben Khaled et al., 2011).

This work was performed to characterize of alkaline proteases extracted from the viscera of Silver carp (Hypophthalmichthys molitrix) fish. Also, effect of partial purification by different methods of the enzyme activity was studied.

\section{Materials and methods:}

\subsection{Materials:}

\subsubsection{Fish sample:}

Fresh Silver carp (Hypophthalmichthys molitrix) fish (average weight 500-900g for each specimen) were bought from privet Aquaculture Farm located at Trompat 7- Kafr ElSheikh Governorate, Egypt. Fish were placed in an icebox and immediately transferred to the laboratory of Food Science and Technology Department, Faculty of Agriculture, Tanta University.

\subsubsection{Chemicals:}

Milk soluble casein was bought from Sigma (USA), Tris-HCl was obtained from LabaChemie (MumbaiIndia), trichloroacetic acid (TCA) was purchased from SDFCL FineChem Limited (Mumbai-India) and ammonium sulfate was obtained from ADWIC EL-Nasr pharmaceutical Chemicals Co. Sephadex G-50 was supplied from Pharmacia (Uppsala Sweden).

\subsection{Methods}

\subsubsection{Preparation of crude alka-} line proteases:

Alkaline proteases were prepared from fresh Silver carp fish in the form of acetone extract powder. The fresh fish were eviscerated to separate viscera using a sharp knife. The separated viscera was defatted by 8 volumes of cold acetone $\left(-18^{\circ} \mathrm{C}\right)$ for $30 \mathrm{sec}$ in homogenizer (Hamilton Beach, southern Pines, North Carolina, USA) at high speed. The homogenate was filtered through filter paper (Whatman no. 40) and the residual material was washed several times with acetone. Finally the residue was washed up with $50 \mathrm{ml}$ of diethyl ether and dried overnight at room temperature. The obtained powder was kept in brown glass and stored at $-18^{\circ} \mathrm{C}$ for further analysis.

2.2.2. Protein assay of the prepared crude enzyme

Protein content of crude alkaline proteases preparation was calorimetrically determined according to Brad (1976) method using Coomassie Plus $^{\mathrm{TM}}$ Protein Assay Kit (Thermo Scientific, Illinois, USA) and bovine serum albumin BSA (included in the kit) as a standard protein. Absorbance was measured at $595 \mathrm{~nm}$ using visible Spectrophotometer (UV-Visible Spectrophotometer-UV 1901PCPhenix-Chain).

\subsubsection{Characterization of the pre- pared crud enzyme}

\subsubsection{Selection of optimum buffer:}

Tow buffers namely sodium phosphate and Tris- $\mathrm{HCl}$ at $0.2 \mathrm{M}$ and $\mathrm{pH} 8$ were prepared. Alkaline prote- 
ases activity was carried out according to the method of Caramori et al. (2011) with slight modification as follows:

Accurate one $g$ of acetone powder was dissolved in $100 \mathrm{ml}$ buffer to prepare $1.0 \%$ acetone powder (as crude enzyme). Added $2.0 \mathrm{ml} 0.5 \%$ casein in $0.2 \mathrm{M}$ Tris- $\mathrm{HCl}$ buffer with $1.0 \mathrm{ml} 1.0 \%$ acetone powder in $20-\mathrm{ml}$ test tube. The mixture was incubated at $37^{\circ} \mathrm{C}$ in water bath for $10 \mathrm{~min}$. The reaction was stopped by adding 1.0 $\mathrm{ml}$ of $5.0 \%$ TCA, centrifuged at 10,000rpm for $15 \mathrm{~min}$ at room temperature. The supernatant was transferred to $10-\mathrm{ml}$ measuring flask and the volume was brought to the mark with distilled water. Absorbance was measured at $280 \mathrm{~nm}$ in Spectrophotometer (UV-Visible Spectrophotometer, - UV 1901PC- PhenixChain) against blank. Where, blank is carried out by incubated the substrate without enzyme then added $1.0 \mathrm{ml}$ of $5.0 \%$ TCA.

2.2.3.2. Determination the optimum pH:

The optimum $\mathrm{pH}$ was determined by measuring the activity of the prepared crud enzyme in $0.2 \mathrm{M}$ Tris- $\mathrm{HCl}$ buffer at various $\mathrm{pH}$ 's (7.5, 8.0, 8.5 and 9.0), according to Yanez et al. (2005).

\subsubsection{Determination of opti- mum temperature:}

The optimum temperature was determined by measuring the activity of the prepared crud enzyme in $0.2 \mathrm{M}$ Tris- $\mathrm{HCl}$ buffer at optimum $\mathrm{pH} 8.5$ and various temperatures $(35,40,45$ and $50^{\circ} \mathrm{C}$ ) according to Yanez et al. (2005).

2.2.3.4. Determination of optimum substrate concentration:
Activity of the prepared crud enzyme at various enzyme concentrations $(0.5,1.0,1.5,2.0$ and $5.0 ; \mathrm{p} / \mathrm{p})$ (protein enzyme / protein substrate) using $0.2 \mathrm{M}$ Tris- $\mathrm{HCl}$ at $\mathrm{pH} 8.5$ and $45^{\circ} \mathrm{C}$ was determined according to Kalpana Dev et al. (2008).

\subsubsection{Determination of thermo-} stability:

Thermo-stability of crud prepared alkaline protease was evaluated by incubation the enzyme-substrate mixture $\left(1: 5 \quad \mathrm{P}_{\mathrm{E}}: \mathrm{P}_{\mathrm{S}}\right)$ using casein $(0.5 \%$ as substrate $)$ at different temperatures $(30,40,45,50,60$ and $70^{\circ} \mathrm{C}$ ) for $60 \mathrm{~min}$. The activity was determined according to Ktari et al. (2014).

\subsubsection{Determination of $\mathrm{pH}$ sta-} bility:

The $\mathrm{pH}$ stability was evaluated by incubated the prepared crud enzyme at various $\mathrm{pH}(8.0,8.5,9.0,10$ and 11.0) for $60 \mathrm{~min}$. Residual activity was determined at $45^{\circ} \mathrm{C}$ using $0.5 \%$ casein as substrate according to Ktari et al. (2014).

\subsubsection{Purification of the prepared crud enzyme:}

2.2.4.1. Ammonium sulfate precipitation:

The crud alkaline protease was mixed with ammonium sulfate at $20 \%, 40 \%$ and $60 \%$ saturation. The mixture was incubated at $4^{\circ} \mathrm{C}$ for $24 \mathrm{hrs}$. Then the mixture was centrifuged at $10,000 \mathrm{rpm}$ at $4^{\circ} \mathrm{C}$ for 30min and discarded the supernatant (EL-Beltagy et al., 2005). The pellets were re-dissolved in $0.2 \mathrm{mM}$ Tris- $\mathrm{HCl}$ buffer at $\mathrm{pH} 8.5$ and dialyzed against the same puffer at $4{ }^{\circ} \mathrm{C}$ in the refrigerator for 24hrs. After that enzyme activity 
was determined at $45^{\circ} \mathrm{C}$ using $0.5 \%$ soluble milk casein as substrate according to Kishimura et al. (2005).

\subsubsection{Gel filtration:}

Crude prepared alkaline protease was purified by gel filtration technique using Sephadex G-50 according to Atta (1986). The enzyme was loaded into Sephadex G-50 column $(5 \mathrm{~cm}$ long $\times 20 \mathrm{~mm})$ at $4{ }^{\circ} \mathrm{C}$ using Tris- $\mathrm{HCl}$ buffer at $\mathrm{pH} 8.5$ as an eluting solvent. Fractions were collected each $1.0 \mathrm{ml}$ in $1.5-\mathrm{ml}$ Eppendorf tubes. The collected fractions were subjected to protein assay and enzyme activity as mentioned above.

\subsubsection{Ultrafiltration:}

Crude prepared alkaline protease was purified by Ultrafiltration using polyamide membrane (cut off $30 \mathrm{KDa}$ ). The proteases activity was determined in the filtrate at $45^{\circ} \mathrm{C}$ using $0.5 \%$ casein in Tric- $\mathrm{HCl}$ buffer as substrate as mentioned above.

\section{Results and Discussions}

\subsection{Characterization of enzyme preparation:}

3.1.1. Selection of optimum buffer:

The results indicated that optimal buffer for alkaline proteases activity was Tris-HCl, which was better than that of sodium phosphate buffer. This may be related to Tris- $\mathrm{HCl}$ is very freely soluble in water, inert in many enzymatic systems and has a high buffer capacity. This result agrees with those reported by Kishimura et al.(2007) and Klomkla et al. (2011).

\subsubsection{Determination of optimum pH:}

The highest significantly enzyme activity of crude alkaline proteases $(2.5 \mathrm{U} / \mathrm{mg})$ was achieved at $\mathrm{pH}$ 8.5 among the other tested pH's (Fig 1). Similar results for trypsin extracted from viscera of hybirid cat fish were reported by (Klomkla et al., 2011). Similar results were obtained from trypsin activity extracted from the viscera of Monterey sardine Kishimura et al. (2006) or true sardine (Yanez et al., 2005) and alkaline proteases extracted from digestive system of carp (Catla catla) (Khangembam et al., 2012). In this reported, (Marcuschi et al., 2010) pointed out that trypsin extracted from the digestive system of fish is normally active in the alkaline region (from $\mathrm{pH}$ 7-12) using BAPNA as a model of substrate.

This may be related to the activity of alkaline proteases normally does not work in the acidic side, whoever the protein of the enzyme could be denaturated in the acidic medium (Klomkla et al., 2011). 




Fig (1): Optimum $\mathrm{pH}$ of crud alkaline proteases extracted from the viscera of Silver carp (Hypophthalmichthys molitrix) fish

\subsubsection{Determination of optimum temperature:}

The significantly highest activity of crude prepared enzyme $(3.31 \mathrm{U} / \mathrm{mg})$ was found at $45^{\circ} \mathrm{C}$. Similar results were obtained for alkaline proteases extracted from the viscera of Tilapia fish (EL-Beltagy et al., 2005) but slightly higher than that of purified trypsin extracted from the digestive system of carp fish (Khangembam et al., 2012) and lower than that purified trypsin extracted from the viscera of hybrid cat fish (Clarias gariepinus) (Klomkla et al., 2011) or pyloric caeca of jacopever (Sebastes schlegelii), elkhorn sculpin (Alcichthys alcicornis) (Kishimura et al., 2007) and zebra blenny (Salaria basilisca) (Ktari et al., 2012). These differences may be related to the variation in the environment conditions including the temperature and type of food (RungruangsakTorrissen, 2016).

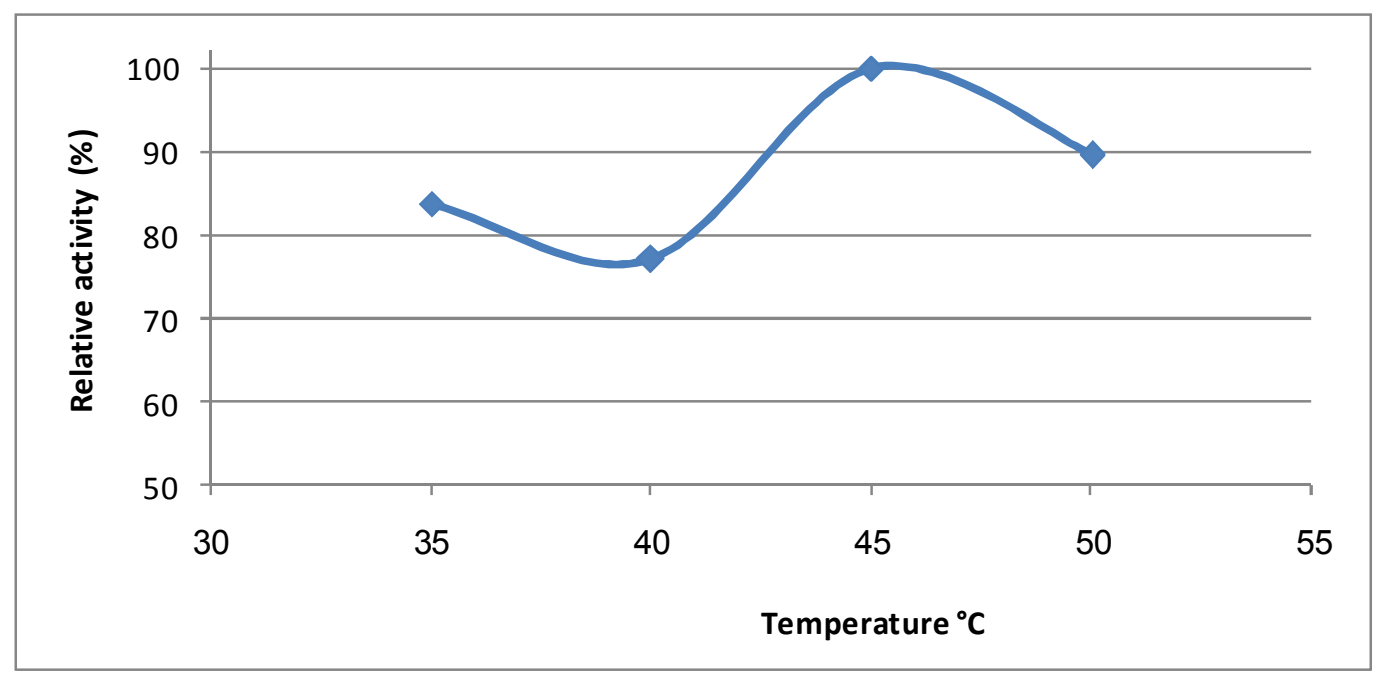

Fig (2): Optimum temperature of crud alkaline proteases extracted from the viscera of Silver carp (Hypophthalmichthys molitrix) fish 
3.1.4. Determination of optimum substrate concentration:

Results of (Fig., 3) revealed that the highest significantly activity was $1: 5\left(\mathrm{p}_{\mathrm{E}}: \mathrm{p}_{\mathrm{S}}\right)$ among the other tested concentration $(0.5: 5,1.0: 5,1.5: 5$ and $2: 5 \mathrm{p}_{\mathrm{E}}: \mathrm{p}_{\mathrm{S}}$ ). This result more than that reported by Dey and Dora (2011) for shrimp waste protein hydrolysis using microbial proteases $(1: 2 \%)$.



Fig (3): Relative activity of alkaline proteases extracted from the viscera of Silver carp (Hypophthalmichthys molitrix) fish as affected by substrate concentration

\subsubsection{Thermo-stability:}

The thermo-stability of alkaline proteases prepared enzyme was achieved at 40 to $50^{\circ} \mathrm{C}$. This result is in agreement with Kishimura et al. (2006) for trypsin extracted from the viscera of true sardine. Also, Barkia et al. (2010) found that purified trypsin was highly stable below $40^{\circ} \mathrm{C}$ and begin to inactivate at higher tempera- tures. These differences in thermal stability of enzyme stabilization could be related to the effect of temperature on the unfolding of aboenzyme (protein moite of enzyme) and change the active center, thus enzyme-substrate binding become difficult at high temperature than $40^{\circ} \mathrm{C}$. As a result, enzyme turns to in active one. 


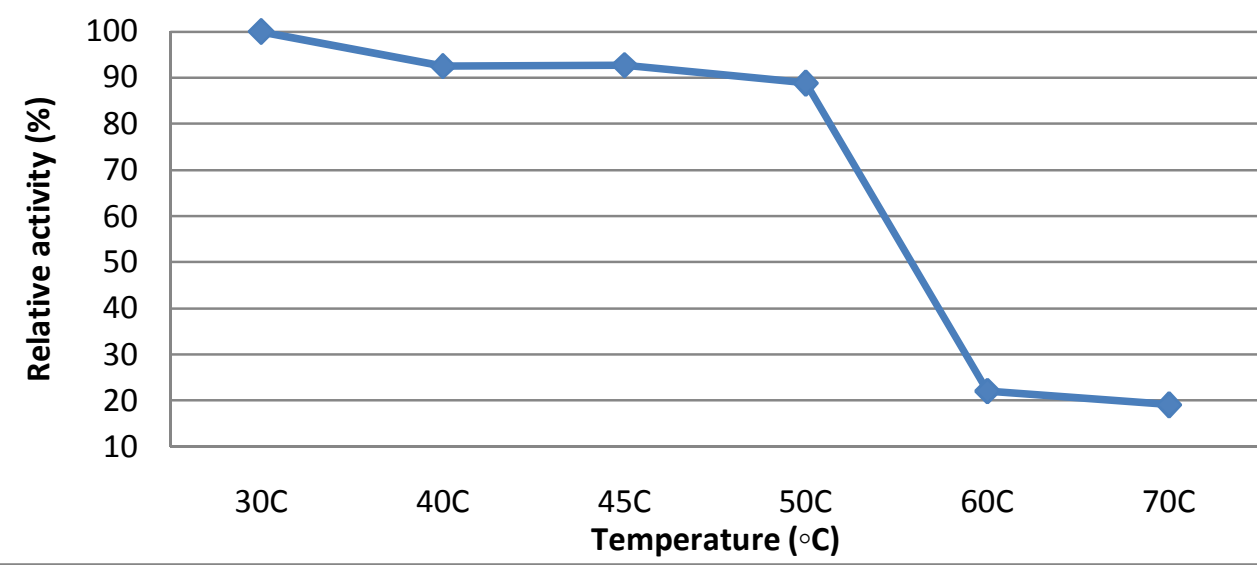

Fig (4): Thermo-stability of crud alkaline proteases extracted from viscera of Silver carp (Hypophthalmichthys molitrix) fish

\subsubsection{The pH stability:}

Maximum relative activity of prepared alkaline proteases was $(0.40 \mathrm{U} / \mathrm{ml})$ achieved at $\mathrm{pH} 8.5$ for $30 \mathrm{~min}$, which is not significantly different than that at $\mathrm{pH} 9.0$ for $30 \mathrm{~min}$ $(0.36 \mathrm{U} / \mathrm{ml})$ (Fig.5). On the other hand, relative activity of the prepared enzyme was significantly droped to 0.26 at $\mathrm{pH} 11$.

This result is lower than that at the $\mathrm{pH}$ at ability alkaline proteases extracted from the viscera of Giant cat fish (Pangasianodon gigas) (Vannabun et al., 2014) and Red scorpion fish (Scorpaena scrofa) (Younes et al., 2015) which was $\mathrm{pH}$ 12. On the other hand, the obtained result is higher than that of trypsin extracted from monterey sardine (Sardinops sagax) $(\mathrm{pH} 7.0 \sim 8.0)$ as reported by Yanez et al. (2005)

Enzyme stability is related to protein net charge at a particular $\mathrm{pH}$. The differences in optimal $\mathrm{pH}$ and $\mathrm{pH}$ stability are attributed to the net charge of the active center which is affected by the $\mathrm{pH}$ of the reaction environment (Robinson, 2015).

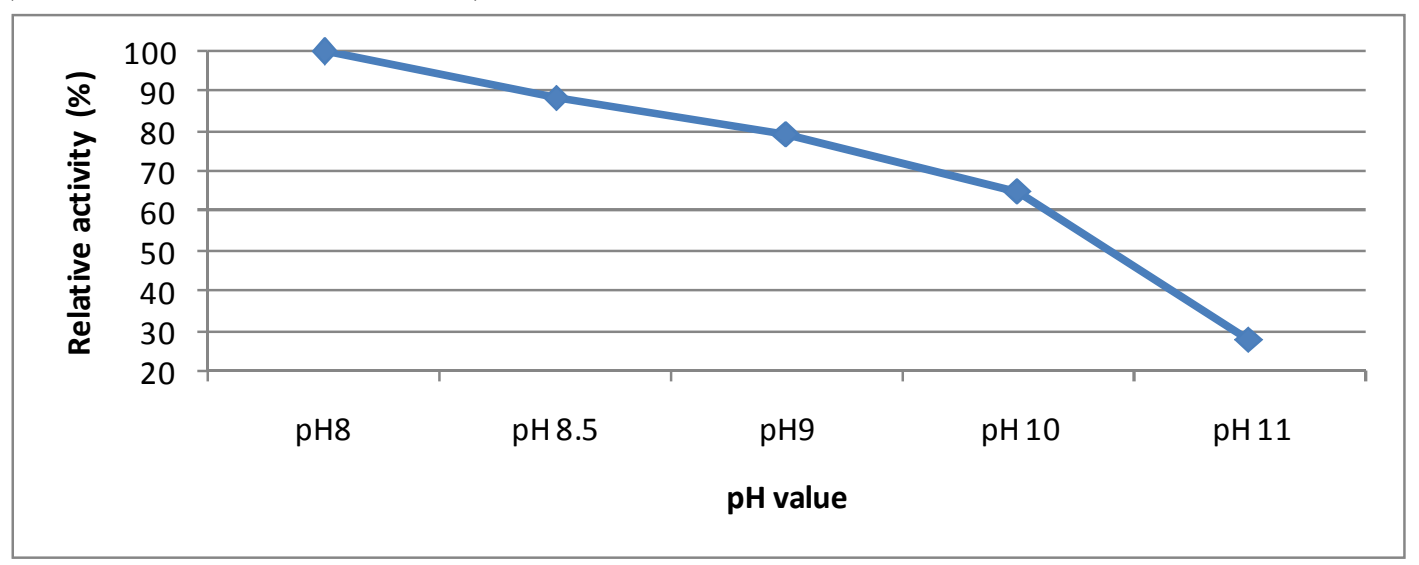

Fig. 5 the pH stability of crude enzyme extracted from the verscera of silver carp (Hypophthalmichthys molitrix) fish 


\subsection{Purification of crude enzyme}

\subsubsection{Ammonium sulfate precipi-} tation:

Specific activity of crude alkaline prepared proteases was augmented after precipitation the enzyme using a saturated ammonium sulfate at $20 \%$. The specific activity was also, increased to reach the significantly highest value after using ammonium sulfate solution saturated at
40\%. After that, the specific activity was dropped to $22 \%$ when the ammonium sulfate solution was saturated at $60 \%$ (Fig.6). This result is close to Ben Khaled et al, (2011) they showed that higher specific activity of trypsin isoforms extracted from viscera of sardinelle (Sardinella aurita) fish preparation was detected by ammonium precipitation at $20-70 \%$ $(\mathrm{w} / \mathrm{v})$.

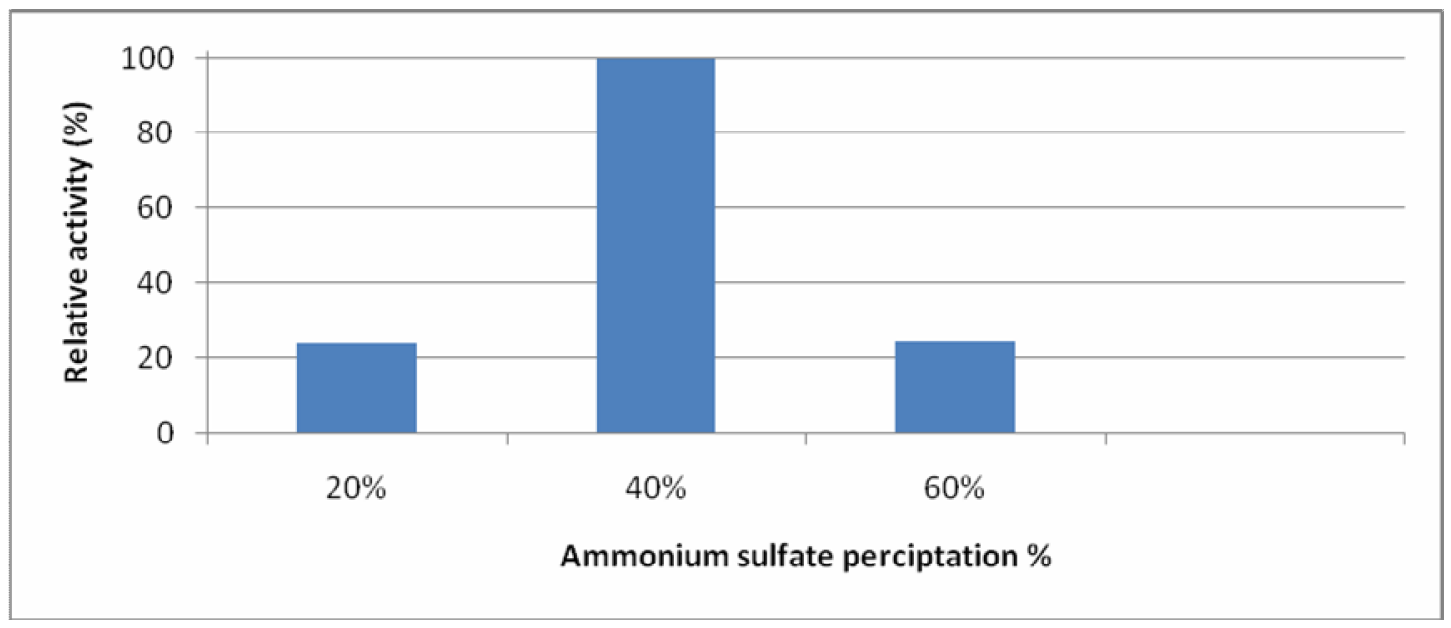

Fig (6): the relative activity of alkaline proteases extracted from the verscera of Silver carp (Hypophthalmichthys molitrix) fish as affected by ammonium sulfate precipitation

\subsubsection{Gel-filtration:}

Purification by gel-filtration technique using Sephedx G-50 column was applied. Tris- $\mathrm{HCl}$ buffer at $\mathrm{pH} 8.5$ was used as eluted solvent. The results show that three fractions only have active enzyme. The significantly highest active fraction (frac- tion no 3) has $0.203 \mathrm{U} / \mathrm{mg}$ followed by fraction no $4(0.11 \mathrm{U} / \mathrm{mg})$, while the first fraction (first one $\mathrm{ml}$ ) does not show active enzyme, where the enzyme activity is binging from the fraction no 2. These result is in agreement with (Ben Khaled et al., 2011). 


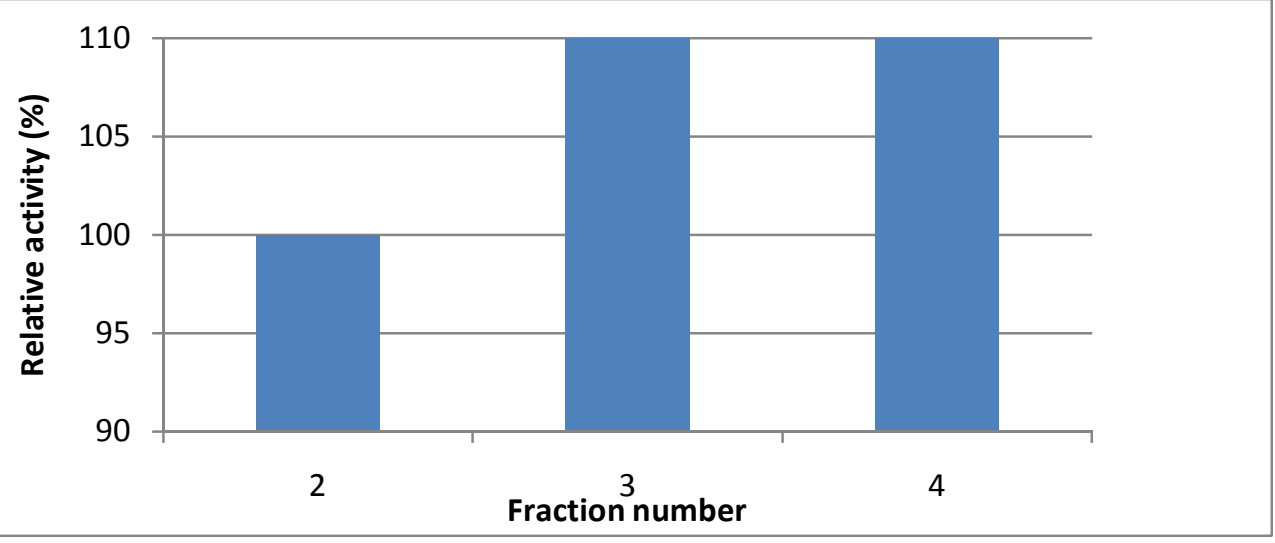

Fig (7): the relative activity of alkaline proteases preparation extracted from the viscera of Silver carp (Hypophthalmichthys molitrix) fish as affected by gel-filtration.

\subsubsection{Ultrafiltration via polyam-} ide membrane (30 KDa):

As shown in Table (1) and Fig.(8), the relative activity of alkaline proteases extracted from the viscera of silver carp was gradually increased according to the purification steps. Where, the significantly highest relative activity of the enzyme was obtained by ultrafiltration technique (139 U/ml) followed by Gel-filtration on the Sephadex column $(21 \mathrm{U} / \mathrm{ml})$ and the lowest one was detected in the crude enzyme $(4.4 \mathrm{U} / \mathrm{ml})$.

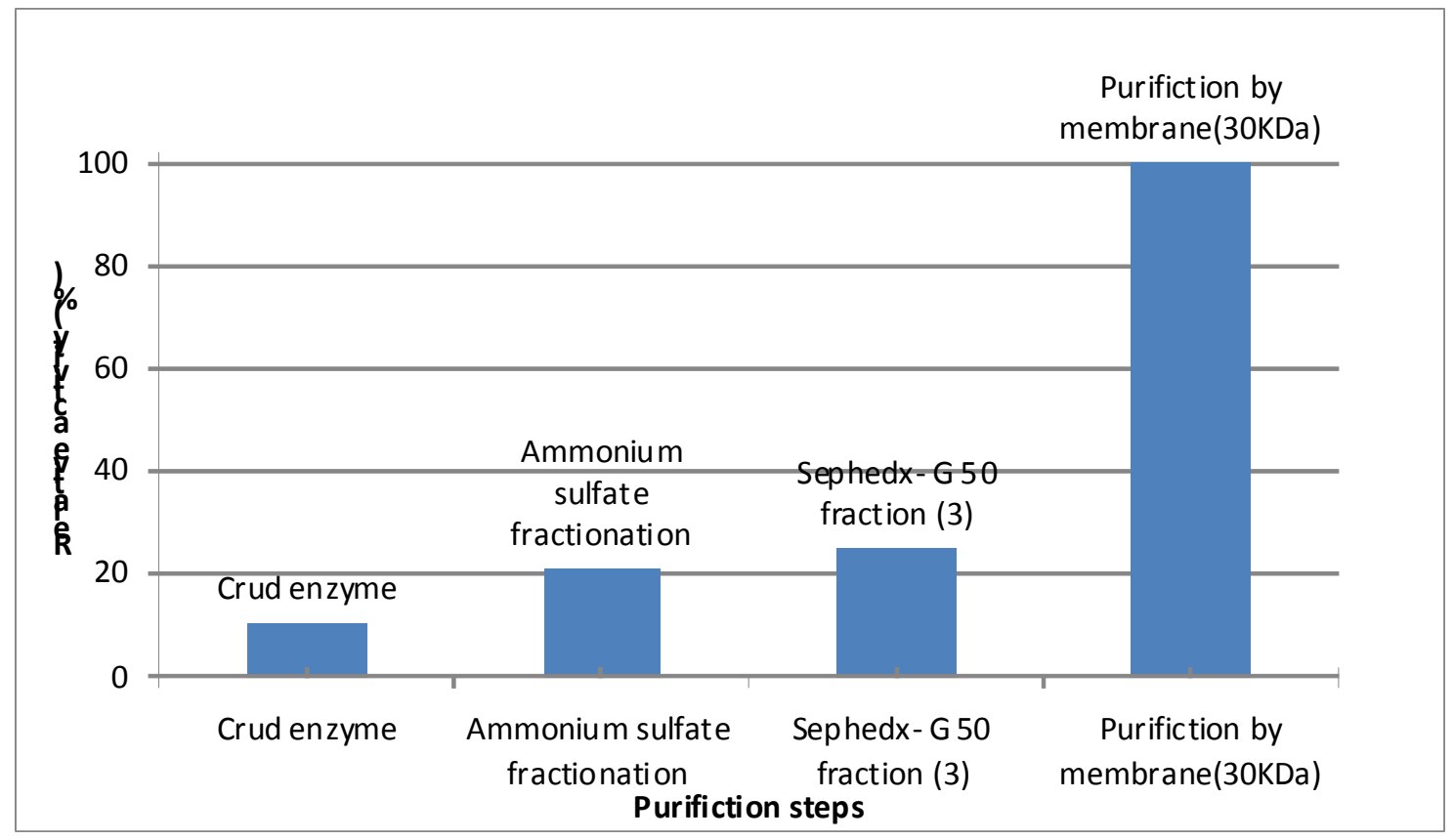

Fig (8): The relative activity of alkaline proteases extracted from the verscera of Silver carp (Hypophthalmichthys molitrix) fish as affected by different purification techniques 
Table (1). Alkaline proteases enzyme activity as affected by purification method.

\begin{tabular}{|l|l|c|c|c|}
\hline Purification phase & $\begin{array}{c}\text { Activity } \\
(\mathbf{U} / \mathbf{m l})\end{array}$ & $\begin{array}{c}\text { Protein } \\
(\mathbf{m g} / \mathbf{m l})\end{array}$ & $\begin{array}{c}\text { Sp Act. } \\
(\mathbf{U} / \mathbf{m g})\end{array}$ & Pure. Fold \\
\hline Crude enzyme & $4.4 \pm 0.43$ & $116.5 \pm 0.68$ & $0.04^{\mathrm{d}} \pm 0.00$ & 1 \\
\hline $\left.\mathbf{( N H}_{4}\right)_{2} \mathbf{S O}_{2} \mathbf{( 4 0 \%}$ preceptation & $22.1 \pm 0.59$ & $28.0 \pm 0.80$ & $0.79^{\mathrm{c}} \pm 0.02$ & 20 \\
\hline Gel Filtration on Sphadex-G50 & $21.0 \pm 0.48$ & $22.7 \pm 0.75$ & $0.92^{\mathrm{b}} \pm 0.04$ & 24 \\
\hline Polyamide Ultrafiltration(30 KDa) & $139.6 \pm 0.45$ & $37.3 \pm 0.63$ & $3.74^{\mathrm{a}} \pm 0.05$ & 99 \\
\hline
\end{tabular}

$\mathrm{M} \pm \mathrm{SD}=$ Means and standard deviation of three successful trails

Sp.Act $=$ specific activity $\mathrm{U} / \mathrm{mg}$ protein

Pure fold $=$ Purification fold

\section{Conclusion:}

Viscera of Silver carp (Hypophthalmichthys molitrix) fish could be use as suitable source of proteases enzymes. These enzymes show high specific activity at $\mathrm{pH} 8.5$ and temperature $45^{\circ} \mathrm{C}$. Purification with ammonium salfat precipitation, gel-filtration by Sephedx G50 fraction and ultrafiltration via polyamide membrane $(30 \mathrm{KDa})$ increase its specific activity up to 20 , 24 and 99fold, respectively. Consequently, fish viscera from silver carp (Hypophthalmichthys molitrix) manufactures offal's could be used as a raw material to extract alkaline proteases enzyme that may be use in different technological uses.

\section{Reference}

Atta, M.B. (1986). Studies on Polysaccharides Macerating Enzymes. Ph.D. Thesis in Food Sci. Tech. Depart, Fac. of Agric, Tanta Univer, Egypt.

Barkia, A.; Bougatef, A.; Nasri, B.; Fetoui, E.; Balti, R.; Nasri, N. (2010). Trypsin from the viscera of Bogue (Boops boops): isolation and characterization. Fish Physiol. Biochem., 36: 893-902.

Ben Khaled, H.; Rym, N.; Bougatef, A.; Ghorbel, Sofiane, Nasri, M. (2011). Low molecular weight serine protease from the viscera of sardinelle (Sardinella aurita) with collagenolytic activity: Purification and characterization. Food Chem., 124: 788-794.

Brad, F. (1976). A rapid and sensitive method for the quantification of microgram quantities of protein utilizing the principle of protein dye binding. Analy. Biochem., 72:248-254.

Caramori, S.; Faria, F.; Vian, M.; Fernandes, K.; Carvalho, B. (2011). Trypsin immobilization on discs of polyvinyl alcohol glutaraldehyde / polyaniline composite. Mater. Sci. Engine., 31:252-257.

Chandrasekaran, M. (2016). Enzymes in Food and Beverage Processing. Baco Raton London New York. Taylor and Francis Group.

Dayanandan, A.; Kanagraj, J.; Sounderraj, L.; Govindaraju, R.; Rajkumar, C. (2003). Application of an alkaline protease in leather processing: an eco-friendly approach. J. Clean Product., 11: 533-536.

Deshpande, V.; Laxman, R.; More, S.; Rele, M.;Rao, B.; Jogdand, V.; Rao, N.; Manikandan, P.; Kumar, D.; Kanakaraj, J.; Samayavaram, R.; Samivelu, N.; Rengarajulu, P. (2004). Process of preparation of alkaline protease. United States Patent, No. 6,777,219B2.

Dettmer, A.; Ayub, Z.; Gutterres, M. (2011). Hide Unhairing and characterization of commercial enzymes used in leather process. 
Brazilian J. Chem. Engine., 28 (3): 373-380.

Dey, S.; Dora, K.(2011). Optimization of the production of shrimp waste protein hydrolysate using microbial proteases adopting response surface methodology. J. Food Sci. Tech., 51(1): 16-24.

EL-Beltagy,E.; $\quad$ EL-Adawy,A.; Rahma,H.; EL Bedawey, A. (2005). Purification and characterization of an alkaline protease from the viscera of Bolti fish (Tilapia nilotica). J. Food Biotechnol. Chem., 29: 445-458.

FAO (2010). Food and Agriculture Organization "Fishery and Aquaculture Country Profiles in The Arab Republic of Egypt". Available on to the internet at: http://www.fao.org/figis/pdf.

FAO. (2016). The State of World Fisheries and Aquaculture 2016. Contributing to food security and nutrition for all, Rome, $200 \mathrm{pp}$.

GAFRD (2012). General Authority for

Fish Resources Development "Value-chain analysis of Egyptian aquaculture". Available on to the internet at:

https://cgspace.cgiar.org/bitstream/ handle/10568/16891/egypt_vca_ 2011.pdf?sequence $=1$.

German, D.; Nagle, B.; Villeda, J.; Ruiz, A.; Thomson, A.; ContrerasBalderas, S.; Evans, D. (2010). Evolution of herbivory in a carnivorous clade of minnows (Teleostei: Cyprinidae): effect on gut size and digestive physiology. Physiolog. Biochem. Zool., 83: 1-18.

Gupta, R.; Beg, Q.; Lorenz, P. (2002). Bacterial alkaline proteases: molecular approaches and industrial applications. Appl. Microbiol. Biotechnol., 59:15-32.

IFC, (2011). International Finance Corporation "Environment, Health and Safety Guidelines for Fish Process- ing". Available on to the internet at:

http://www.ifc.org/ifcext/enviro.ns $\mathrm{f} /$ AttachmentsB.

Jellouli, K.; Bougatef, A.; Daassi, D.; Balti, R.; Barkia, A.; Nasri, M. (2009). New alkaline trypsin from the intestine of Grey trigger fish (Balistes capriscus) with high activity at low temperature: purification and characterization. Food Chem., 116:644-650.

Jiang, H.; Tong, T.; Sun, J; Xu, Y.; Zhao, Z.; Liao, D. (2014). Purification and characterization of antioxidative peptides from round scad (Decapterus maruadsi) muscle protein hydrolysate. Food Chem., 154:158-163.

John,W.; Alphons, V.; Dominic, W. (2003). Handbook of Food Enzymology. Marcel Dekker, Inc.

Kalpana Devi, M.; Rasheedha Banu, A.; Gnanaprabhal, R.; Pradeep, V.; Palaniswamy, M. (2008). Purification, characterization of alkaline protease enzyme from native isolates Aspergillus niger and its compatibility with commercial detergents. Indian J. Sci. Technol., 1 (7): 1-7.

Khangembam, B.; Sharma, K.; Chakrabarti, R. (2012). Purification and characterization of trypsin from the digestive system of carp Catla catla (Hamilton). Inter. Aqua. Res., 4:9-20.

Khoddami, A., Ariffin, A., Bakar, J.; Ghazali, H. (2009). Fatty acid profile of the oil extracted from fish waste (head, intestine and liver) (Sardinella lemuru).World Appl. Sci. J., 7 (1): 127-131.

Kishimura, H.; Klomklao, S.; jakul, S.; Chun, B. (2008). Characteristics of trypsin from the pyloric ceca of walleye pollok (Theragra chlcogramma). Food Chem., 106:194-199. 
Kishimura, H.; Tokuda, Y.; Ando, S.; Klomklao, S.; Benjakul, S.(2006). Enzymatic characteristics of trypsin from pyloric Ceca of spotted mackeral (Scomber australasicus). J. Food Biochem., 30:466-477.

Kishimura, H.; Tokuda, Y.; Yabe, M.; Klomkla, S.; Benjakul. S.; Ando, S. (2007). Trypsins from the pyloric ceca of jacopever (Sebastes schlegelii) and elkhorn sculpin (Alcichthys alcicornis): Isolation and characterization. Food Chem., 100: 1490-1495.

Kishmura, H.; Tkuda, Y.; Klomklao, S,; Benjakul, S.; Ando, S. (2005). Comparative study on enzymatics of trypsins from the Pyloric Ceca of Yellow tail (Seriola quinqueradiata) and Brown Hakeling (Physiculus Japonicus). J. Food Biochem., 30(5): 521-534.

Klomklao, S.; Benjakul,S.; Kishimura, H.; Chaijan, M. (2011). 24 kDa Trypsin: A predominant protease purified from the viscera of hybrid cat fish (Clarias macrocephalus) and (Clarias gariepinus). Food Chem., 129: 739-746.

Ktari, N.; Hayet, B.; Younes, I.; Bkhairia, I.; Mhamdi, S.; Hamza, I.; Nasri, M. (2014). Zebra blenny (Salaria basilisca) viscera as a source of solvent-stable proteases: characteristics, potential application in the deproteinization of shrimp wastes and evaluation in liquid laundry commercial detergents. J. Food Sci. Technol., 51 (11): 3094-3103.

Ktari, N.; Khaled, H.; Nasir, K.; Jellouli, K.; Ghorbel, S.; Nasri, M. (2012). Trypsin from zebra blenny (Salaria basilisca) viscera: Purification, characterization and potential application as a detergent additive. Food Chem., 130: 467-474.

Kumar, G.; Suresh, V. (2016). Sustainable valorisation of seafood by- products: Recovery of collagen and development of collagenbased novel functional food ingredients. Innov. Food Sci. Emerg. Technol. , 37: 201-215.

Kumar, P.; Elsaidi, H.; Zorniak, B.; Laurens, E.; Yang, J.; Bacchu, V.; Wang, M.; Wiebe, L.(2016) Synthesis and Biological Evaluation of Iodoglucoazomycin (IGAZ), an Azomycin Glucose Adduct with Putative Applications in Diagnostic Imaging and Radiotherapy of Hypoxic Tumors. Chem MedChem. 11:1-9.

Lara-Márquez, A.; Zavala-Páramo, G.; López-Romero, E.; Camacho, C. (2011). Biotechnological potential of pectinolytic complexes of fungi. Biotechnol. Lett., 33: 859-868.

Marcuschi, M.; Esposito, T.; Machado, M.; Hirata, I.; Silva,M.; Curralho, L.; Oliveira, V.; Bezerra, R. (2010). Purification, characterization and substrate specificity of a trypsin from the Amazonian fish tambaqui (Colossoma macropomum). Biochem. Biophy. Res. Communic., 396 (3): 667-673.

Mohamed A.; Nasr Allah, M.; El Naggar G. (2012). Egyptian Fish Seed Production Improving Employment and Income Through Development of Egypt's Aquaculture Sector (IEIDEAS) Project April 2012, World Fish Cent., Egypt.

Qian, Z.; Kim, S. (2007). Antihypertensive effect of angiotens in Iconverting enzyme-inhibitory peptide from hydrolysates of bigeye tuna dark muscle, Thunnus obesus. J. Agric. Food Chem., 55:8398-403.

Robinson, K. (2015). Enzymes: principles and biotechnological applications, Essays Biochem., 15 (59):141.

Rungruangsak-Torrissen, K. (2016). Let's Make a Difference in Marine Research on Environmental Impact 
and Climate Change. Ann. Marine Biol. Res., 3(1): 1009-1017.

Sawant, R.; Nagendran, S.(2014). Protease: An enzyme with multiple industrial applications. World J. Pharm. Pharmaceut. Sci., 3(6): 569-579.

Talita, E.; Ian, A.; Diego, B.; Givanildo, O.; Luiz, C.; Ranilson, B. (2009). Fish processing waste as a source of alkaline proteases for laundry detergent, Food Chem., 112: 125130.

Vannabun, A.; Ketnawa, S.; Phongthai, S.; Khaled Hayetjakul, S.; Rawdkuen, S. (2014). Characterization of acid and alkaline proteases from viscera of farmed giant catfish. Food Biosci., 6: 9-16.

Vannuccini, S. (2004). Overview of Fish Production, Utilization, Consumption and Trade Based on 2002 Data Fishery Information: Data and statistics unit food and agriculture organization of United Nations. Available on to the internet at: http://fao.org.

Xiong, D.; Xie, C.; Zhang, H.; Liu, H.(2011). Digestive enzymes along digestive tract of a carnivorous fish Glyptosternum maculatum and Sisoridae siluriformes. J. Anim. Physio. Anim. Nutr., 95: 56-64.

Yanez, F.; Aguilar, R.; Carreno, L.; Toro, M. (2005). Isolation and characterization of trypsin from pyloric caeca of Monterey sardine Sardinops sagax caerulea, Comparative Bioch. Phys Part B 140 (1):91-98.

Younes, I.; Nasri, R.; Bkhairia, I, Jellouli, K.; Nasri, M. (2015). New proteases extracted from red scorpion fish (Scorpaena scrofa) viscera: Characterization and application as a detergent additive and for shrimp waste deproteinization. Food. Bioprod. Process., 94:453462.

Zhang, J.; Duan, R.; Tian, Y.; Konno, K. (2009). Characterization of acid soluble collagen from skin of silver carp (Hypophthalmichthys molitrix). Food Chem., 116: 318-322.

Zhong, S.; Ma, C.; Lin, Y.; Luo, Y. (2011). Antioxidant properties of peptide fractions from silver carp (Hypophthalmichthys molitrix) processing by-product protein hydrolysates evaluated by electron spin resonance spectrometry. Food Chem., 126: 1636-1642.

Zhou, L.; Budge, S.; Ghaly, A.; Brooks, M.; Dave, D. (2011). Extraction, purification and characterization of fish chymotrypsin: A Review, Amer. J. Biochem. Biotechnol., 7(3): 104-123. 
استلاصوتنقية الأزيمات البروتينيهمن لحشاعسك المبروك الضى

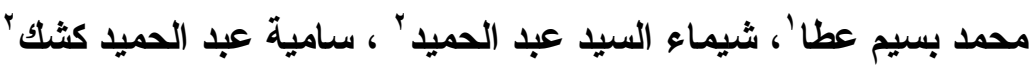

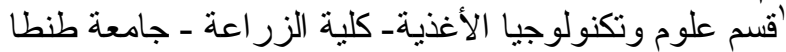

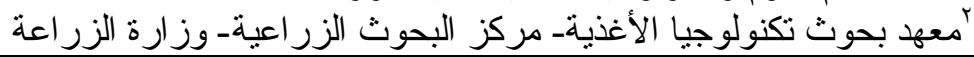





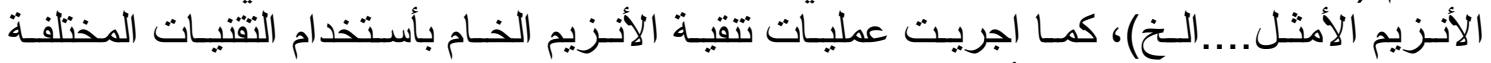

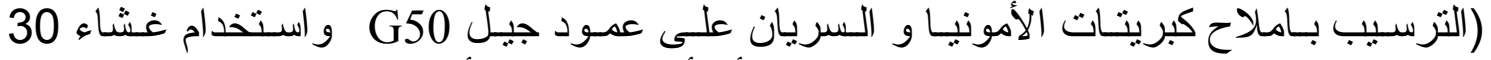

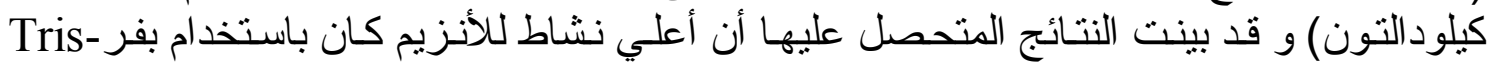

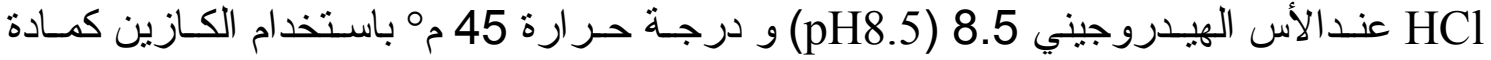



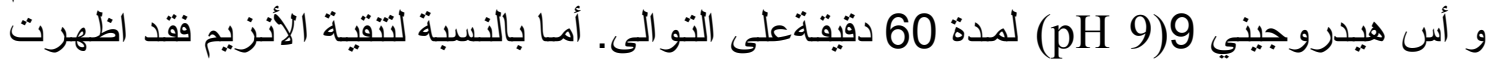

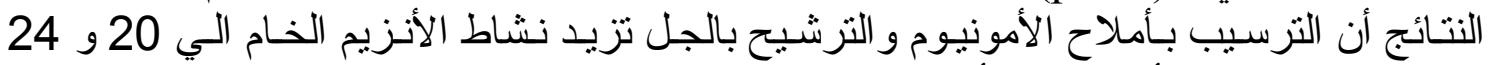

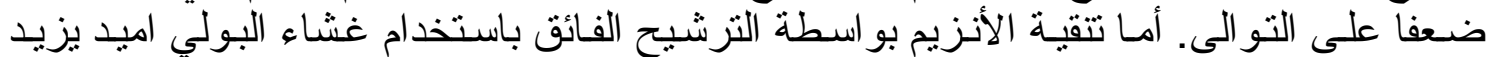
نشاط الأنزيم الي 99 ضعفا. 